\title{
PENGARUH FREKUENSI PEMBERIAN PAKAN YANG BERBEDA TERHADAP PERTUMBUHAN IKAN BANDENG (Chanos chanos)
}

\author{
Umar Faruq ${ }^{1}$, Rahmad Jumadi $^{2}$, Muh. Sulaiman Dadiono ${ }^{3}$, \\ ${ }^{1}$ Mahasiswa Prodi Akuakultur, Fakultas Pertanian Universitas Muhammadiyah Gresik. \\ ${ }^{2}$ Dosen Fakultas Pertanian Universitas Muhammadiyah Gresik. \\ ${ }^{3}$ Dosen Prodi Akuakultur, Fakultas Pertanian Universitas Muhammadiyah Gresik. \\ nindyanarizka@gmail.com;081359986786
}

\begin{abstract}
Milkfish is one type of fish that is widely known and popular for consumption by the people of Indonesia. This is because milkfish has a good taste of meat and affordable prices. This research was conducted in brackish water ponds in Banyu Urip, Ujung Pangkah, Gresik. The purpose of this study was to determine the effect of different feeding frequency on milkfish growth. To determine the effect of different feeding frequencies on the survival of milkfish. The research method used in the experimental design that will be used in this study is a Completely Randomized Design (CRD) with 4 levels of treatment and 3 repetitions. Treatment Treatment A: The frequency of feeding once a day is at $08.00 \mathrm{WIB}$. Treatment B: The frequency of feeding twice a day is at 08.00 WIB and 20.00 WIB. Treatment C: The frequency of feeding three times a day is 08.00 WIB, 12.00 WIB, 20.00 WIB. Treatment D: The frequency of feeding four times a day is at $08.00 \mathrm{WIB}, 12.00 \mathrm{WIB}, 16.00 \mathrm{WIB}$ and 20.00 WIB. By statistical analysis using ANOVA if the effect is done BNT test. The results showed that the survival of milkfish was $100 \%$, the milkfish feed conversion ratio was good in treatment A with 1 time.
\end{abstract}

Keywords : Milkfish, feeding frequency, survival, feed conversion ratio.

\begin{abstract}
ABSTRAK
Ikan bandeng merupakan yang digemari oleh masyarakat Indonesia, karena mempunyai rasa yang enak dan harga yang murah. Penelitian ini dilaksanakan di Tambak air payau di Desa Banyu Urip Kecamatan Ujung Pangkah Kabupaten Gresik. Tujuan penelitian ini adalah untuk mengetahui pengaruh frekuensi pemberian pakan yang berbeda terhadap pertumbuhan ikan bandeng. Untuk mengetahui pengaruh frekuensi pemberian pakan yang berbeda terhadap kelangsunggan hidup ikan bandeng. Metode penelitian yang digunakan rancangan percobaan yang akan digunakan dalam penelitian ini adalah Rancangan Acak Lengkap (RAL) dengan 4 taraf perlakuan dan 3 kali pengulangan. Perlakuan Perlakuan A: Frekuensi pemberian pakan satu kali sehari yaitu pada pukul 08.00 WIB.Perlakuan B: Frekuensi pemberian pakan dua kali sehari yaitu pada pukul 08.00 WIB dan 20.00 WIB.Perlakuan C: Frekuensi pemberian pakan tiga kali sehari yaitu pada pukul 08.00 WIB, 12.00 WIB, 20.00 WIB.Perlakuan D: Frekuensi pemberian pakan empat kali sehari yaitu pada pukul $08.00 \mathrm{WIB}, 12.00 \mathrm{WIB}, 16.00 \mathrm{WIB}$ dan 20.00 WIB. Dengan analisis statistic dengan menggunakan ANOVA jika berpengaruh dilakukan uji BNT. Hasil penelitian menunjukkan bahwa kelangsungan hidup ikan bandeng $100 \%$, Rasio Konversi Pakan Ikan Bandeng yang bagus yaitu pada perlakuan A dengan pemberian 1 kali.
\end{abstract}

Kata kunci : Ikan bandeng, frekuensi pemberian pakan, kelangsunggan hidup, Rasio konversi pakan. 


\section{PENDAHULUAN}

Manajemen pemberian pakan merupakan salah satu usaha yang dilakukan untuk mendukung keberhasilan usaha budidaya. Pemberian pakan diharapkan agar pakan yang diberikan dimanfaatkan oleh ikan secara efektif dan efisien sehingga menghasilkan pertumbuhan ikan yang optimal. Pengaturan frekuensi pemberian pakan merupakan salah satu manajemen pemberian pakan. Pembudidaya pada umumnya memberikan pakan pada ikan budidaya hanya menurut kebiasaan, tanpa mengetahui tentang kebutuhan nutrisi masing-masing organisme budidaya meliputi kualitas, kuantitas dan waktu pemberian pakan. Pemberian pakan dengan waktu yang berbeda akan mempengaruhi pertumbuhan ikan (Subandiyono dan Hastuti 2011).

Rata-rata di Kabupaten Gresik Petambak/Petani masih menggunakan cara tradisional atau tanpa menggunakan pakan dan laju pertumbuhan masih lambat dan belum bisa memenuhi permintaan dalam negeri maupun luar negeri (Rahim, 2018; Rahim, 2018; Rahim et al., 2016; Rahim et al., 2015). berdasarkan hal tersebut, diperlukan adanya penilitian tentang frekuensi pemberian pakan yang tepat bagi upaya pembudidayaan ikan bandeng (Chanos chanos).

\section{METODE PENELITIAN}

\section{Alat dan Bahan}

Bahan yang digunakan dalam penelitian ini adalah ikan bandeng umur 20 hari sebanyak 600 ekor, yang sudah glondongan yang di peroleh dari petani glondongan bandeng di Kabupaten Gresik.

Adapun peralatan yang akan digunakan dalam penelitian ini adalah: $\mathrm{pH}$ paper untuk mengukur $\mathrm{pH}$ air, Termometer untuk mengukur suhu air, Timbangan digital untuk menimbang bobot ikan, Ember plastik untuk tempat sampel ikan, Serok halus untuk mengambil sampel ikan, Sikat untuk membersihkan jaring percobaan, Alat tulis, Kamera digital untuk dokumentasi, Jaring ukuran $0,5 \mathrm{~mm}$ dengan luasan $50 \times 50 \mathrm{~cm}^{2}$ sebanyak 3 buah yang disekat menjadi 4 petak, dan tongkat penyangga.

\section{Perlakuan dan Rancangan Percobaan}

Rancangan percobaan yang akan digunakan dalam penelitian ini adalah Rancangan Acak Lengkap (RAL) dengan 4 taraf perlakuan dan 3 kali pengulangan. Perlakuan yang dicobakan adalah tingkat frekuensi pemberian pakan. Perlakuanperlakuan yang akan digunakan adalah sebagai berikut:

Perlakuan A: Frekuensi pemberian pakan satu kali sehari yaitu pada pukul 08.00 WIB.

Perlakuan B: Frekuensi pemberian pakan dua kali sehari yaitu pada pukul 08.00 WIB dan 20.00 WIB.

Perlakuan C: Frekuensi pemberian pakan tiga kali sehari yaitu pada pukul 08.00 WIB, 12.00 WIB, 20.00 WIB.

Perlakuan D: Frekuensi pemberian pakan empat kali sehari yaitu pada pukul 08.00 WIB, 12.00 WIB, 16.00 WIB dan 20.00 WIB.

\section{Varibel Pengamatan}

\section{Laju Pertumbuhan Harian}

Merupakan laju petumbuhan harian, persentase pertambahan bobot per hari. Adanya variasi ukuran pada akhir pemeliharaan terkait dengan pemberian pakan buatan pada media dengan dosis yang berbeda. Untuk menentukan laju pertumbuhan spesifik sesuai dengan Handajani dan Widodo (2010):

$$
S G R=\frac{L n W t-L n W o}{t} \times 100 \%
$$


Keterangan :

SGR : Laju pertumbuhan harian rata - rata ( \% )

$\mathrm{Wt}:$ Berat rata - rata pada $\mathrm{t}(\mathrm{g})(\mathrm{I}=$ minggu $\mathrm{I}$, minggu $\mathrm{II}, \mathrm{t})$

Wo : Berat rata - rata pada $\mathrm{t}(\mathrm{g})$

$\mathrm{T} \quad$ : Periode penanaman ( hari )

\section{Bobot Mutlak}

Bobot mutlak diukur dengan pengambilan sampel sebanyak 5 ekor dari masingmasing perlakuan pada setiap ulangan, untuk di timbang bobotnya. Bobot mutlakuji dapat dihitung dengan menggunakan rumus menurut Handajani dan Widodo (2010):

$$
\mathrm{W}_{\mathrm{m}}=\mathrm{W}_{\mathrm{t}}-\mathrm{W}_{0}
$$

Keterangan :

$W_{m} \quad$ : Pertumbuhan Bobot Mutlak Rata-rata (gram)

$W_{t} \quad$ : Bobot Rata-rata Ikan pada Akhir Penelitian (gram)

$W_{0} \quad$ : Bobot Rata-rata Ikan pada Awal Penelitian (gram)

\section{Panjang Mutlak}

Panjang mutlak diukur dengan pengambilan sampel sebanyak 5 ekor dari masing-masing perlakuan pada setiap ulangan, untuk di ukur panjangnya. Panjang mutlak dihitung dengan modifikasi rumus Kordi, (2013) :

Keterangan :

$$
\mathrm{P}_{\mathrm{h}}=\frac{L t-L o}{t} \times 100 \%
$$

$\begin{array}{ll}\mathrm{P}_{\mathrm{h}} & \text { : Pertumbuhan panjang harian }(\%) \\ \mathrm{Lt} & \text { : Panjang rata-rata akhir }(\mathrm{cm}) \\ \mathrm{Lo} & \text { : Panjang rata-rata awal }(\mathrm{cm}) \\ \mathrm{T} & \text { : Lama pemeliharaan (hari) }\end{array}$

\section{Rasio Konversi Pakan/ (feed convertion ratio, FCR)}

Rasio Konversi Pakan yaitu perbandingan (rasio) antara berat pakan yang telah diberikan dalam satu siklus periode budidaya dengan berat total (biomass) ikan yang dihasilkan pada saat itu di rumuskan Kordi, (2013)

Keterangan :

$$
\mathrm{FCR}=\frac{F}{W t-W o}
$$

FCR : Feed Convertion Ratio

$\mathrm{F} \quad$ : Jumlah pakan yang diberikan selama pemeliharaan $(\mathrm{kg})$

Wo : Berat total ikan pada waktu tebar $(\mathrm{kg})$

Wt : Berat total ikan pada waktu panen $(\mathrm{kg})$

\section{Parameter Kualitas Air}

Penghitungan parameter penunjang yang diamati dalam penelitian ini adalah suhu dengan thermometer, oksigen terlarut dengan $\mathrm{DO}$ meter, $\mathrm{pH}$ dengan $\mathrm{pH}$ meter, dan salinitas. Pengukuran dilakukan 1minggu sekali selama penelitian berlangsung. 


\section{HASIL DAN PEMBAHASAN}

\section{Kelangsungan Hidup/ (survival rate, SR)}

Tingkat kelangsungan hidup ikan bandeng yang dipelihara selama 35 hari pada semua perlakuan tidak mengalami kematian. Dengan persentase ikan yang hidup berjumlah $100 \%$.

Menurut Reksono et al., (2012), bahwa kualitas air turut mempengaruhi tingkat kelangsungan hidup dan pertumbuhan dari organisme perairan yang dibudidayakan, dan didukung oleh pernyataan Serdiati et al., (2011). Menyatakan bahwa derajat kelangsungan hidup disebabkan oleh banyak faktor, satu diantaranya adalah padat tebar ikan yang terlalu tinggi. Dimana Efesiensi pakan dapat dilihat dari beberapa faktor dimana salah satu diantaranya adalah rasio konversi pakan.

\section{Laju Pertumbuhan Harian}

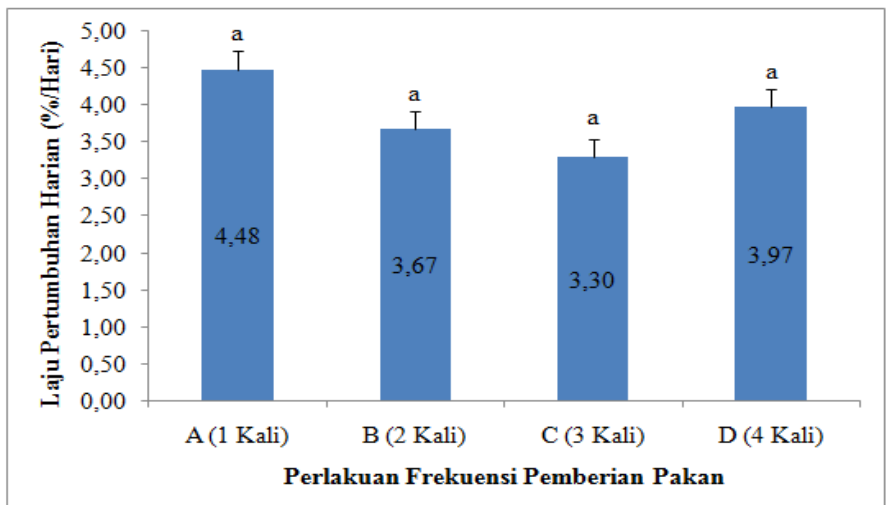

Gambar 1. Grafik Laju Pertumbuhan Harian

Rata-rata pertumbuhan bobot harian ikan bandeng pada perlakuan A : 4,48\%, B: $3,67 \%$, C : 3,30\%, dan D : 3,97\%. Pertumbuhan bobot harian bandeng yang tertinggi yaitu pada perlakuan A dengan pemberian 1 kali dengan nilai sebesar 4,48\%. Pertumbuhan bobot harian ikan bandeng yang terendah ditunjukkan pada perlakuan $\mathrm{C}$ dengan pemberian pakan 3 kali dengan nilai pertumbuhan bobot harian ikan bandeng sebesar 3,30\%. Dari analisa ANOVA didapatkan bahwa nilai F1\%>F5\%>F hitung.

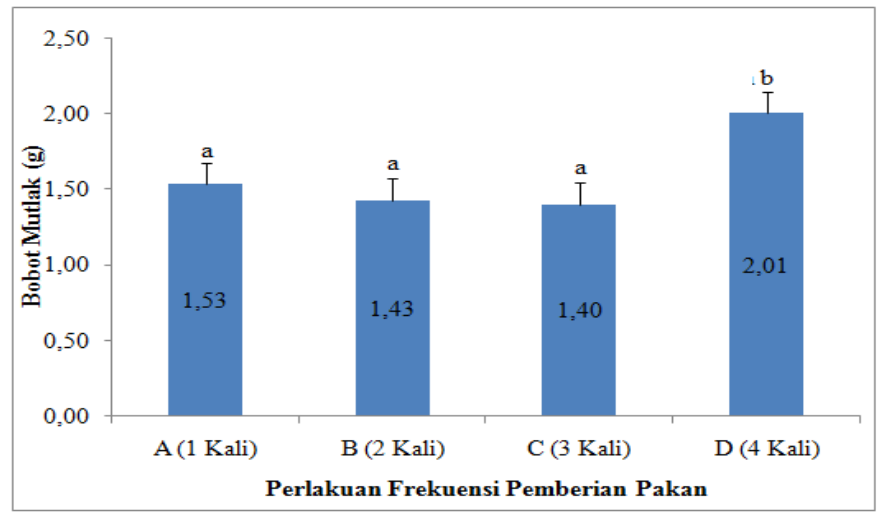

Gambar 2. Grafik Laju Bobot Mutlak

Dari grafik bobot mutlak diatas dapat disimpulkan rata-rata laju pertumbuhan bobot mutlak Ikan Bandeng perlakuan A : 1,53 g, B: 1,43 g, C : 1,40 g, dan D : 2,01 g. bobot mutlak ikan bandeng yang tertinggi yaitu pada perlakuan $\mathrm{D}$ dengan pemberian 4 
kali dengan nilai sebesar 2,01 g. Bobot mutlak Ikan Bandeng yang terendah ditunjukkan pada perlakuan A dengan pemberian pakan 1 kali dengan nilai sebesar 1,53 gram. Pemberian Pakan sebanyak 4 kali mampu memicu bobot mutlak ikan bandeng lebih baik. Berdasarkan hasil penelitian, bobot mutlak lebih tinggi dari pada pertumbuhan panjang dalam waktu yang sama, hal ini menunjukan ikan bandeng tumbuh gemuk. Hasil Analisa ANOVA didapatkan nilai F5\%<F1\%<F hitung.

\section{Panjang Mutlak}

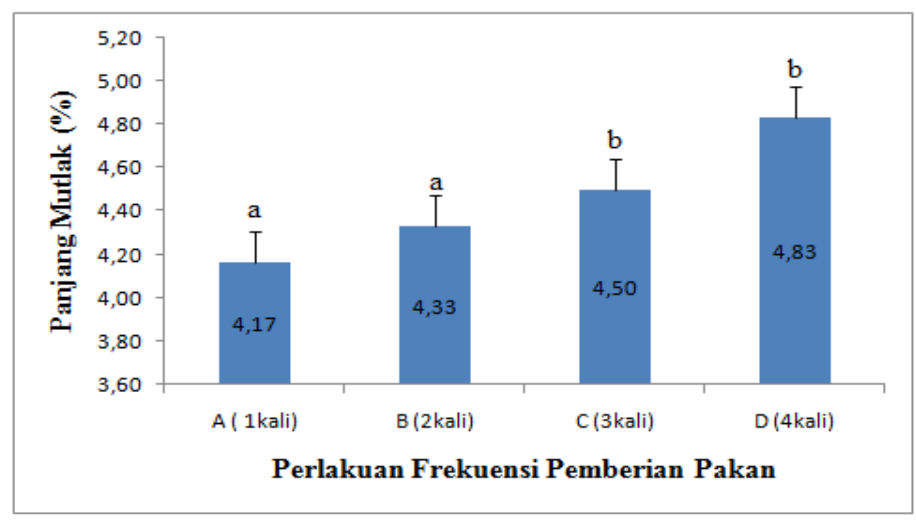

Gambar 3. Grafik Panjang Mutlak

Grafik panjang mutlak diatas dapat disimpulkan rata-rata panjang mutlak Ikan Bandeng pada perlakuan A : 4,17, B: 4,33, C : 4,50, dan D : 4,83. Panjang mutlak ikan bandeng yang bagus yaitu pada perlakuan $\mathrm{C}$ dengan pemberian 3 kali dengan nilai sebesar 4,50. Panjang mutlak ikan bandeng yang terendah ditunjukkan pada perlakuan A dengan pemberian pakan 1 kali dengan nilai panjang mutlak ikan bandeng Bandeng sebesar 4,17. Dari analisa ANOVA menunjukan bahwa nilai F1\% $>\mathrm{F} 5 \%<\mathrm{F}$ hitung.

\section{Rasio Konversi Pakan/ (feed conversion ratio, FCR)}

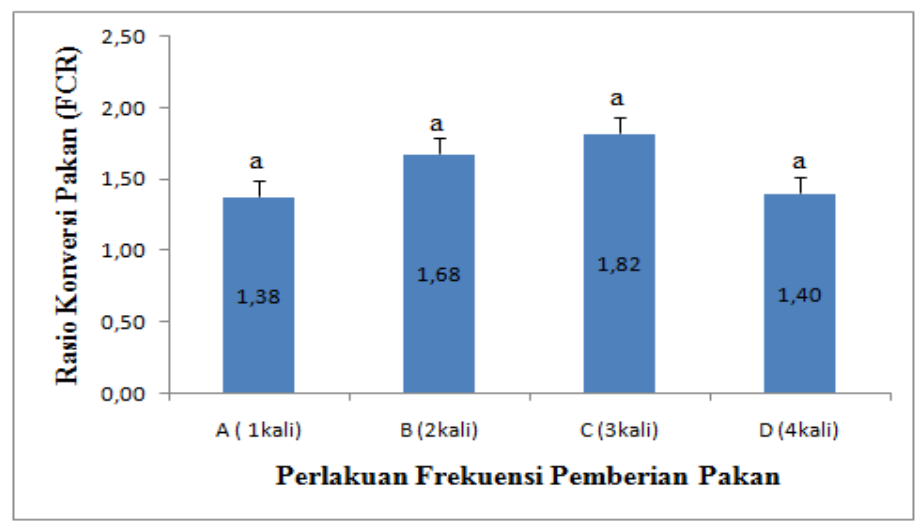

Gambar 4. Grafik Rasio Konversi Pakan

Grafik Rasio Konversi Pakan diatas dapat disimpulkan rata-rata Rasio Konversi Pakan (FCR) Ikan Bandeng pada perlakuan A : 1,38, B: 1,68, C : 1,82, dan D : 1,40. Rasio Konversi Pakan Ikan Bandeng yang terendah yaitu pada perlakuan A dengan pemberian 1 kali. Konversi Pemberian Pakan Bandeng yang tertinggi ditunjukkan pada perlakuan $\mathrm{C}$ dengan pemberian pakan 3 kali dengan nilai Konversi Pemberian Pakan (FCR) Ikan Bandeng sebesar 1,82.

Menurut Serdiati et al., (2011), semakin rendah angka konversi pakan, semakin sedikit pakan yang dibutuhkan untuk menghasilkan $1 \mathrm{~kg}$ daging ikan. Artinya, semakin 
efesien pakan tersebut diubah menjadi daging. Tingkat efesiensi penggunaan pakan pada ikan bandeng ditentukan oleh pertumbuhan dan jumlah pakan yang diberikan. Analisa ANOVA didapatkan bahwa nilai F1\%>F5\%>F hitung.

\section{Kualitas Air}

Hasil pengamatan kualitas air didapatkan suhu air media budidaya berkisar 29,3 30,7 pada pagi hari dan 29,0 - 31,2 pada sore hari dalam hal ini suhu media budidaya dapat dikatakan konstan dan tidak fluktuatif. Menurut Affan (2012), peningkatan suhu dapat menurun kadar oksigen terlarut dan mempengaruhi metabolisme juga kadar karbon dioksida. Mayunar et al., (1995) menyebutkan suhu optimum untuk budidaya ikan adalah $27-32{ }^{\circ} \mathrm{C}$.

Hasil pengamatan $\mathrm{pH}$ media budidaya pada pagi hari berkisar 8,05 - 8,25, sedangkan pada sore hari 8,06 - 8,29. Berdasarkan hasil pengukuran kualitas air selama penelitian menunjukkan nilai kisaran yang masih dalam batas normal, hal ini diperkuat pendapat Dadiono et al., (2017), bahwa perairan dengan $\mathrm{pH}$ antara 7,6 - 8,6 masih dapat dikatakan dalam batas normal. Berdasarkan hasil tersebut dapat diketahui bahwa $\mathrm{pH}$ tidak mengalami fluktuasi yang signifikan.

DO tertinggi didapatkan pada minggu ke 2 sore yaitu $6,7 \mathrm{ppm}$ dan terendah pada minggu pertama pagi yaitu 6,1 ppm. Salinitas media budidaya berkisar 18-20 ppt. Salinitas terrendah terjadi pada minggu ke 1 . Hal ini disebabkan terjadinya hujan sehingga dapat mengurangi kadar garam pada tambak sekitar 2 ppt. Menurut Karina et al., (2011), salinitas 30 ppt adalah tingkat kadar garam normal pada air laut, pada salinitas ini induk ikan bandeng dipelihara.

\section{KESIMPULAN}

Berdasarkan hasil penelitian dapat disimpulkan bahwa pemberian frekuensi pakan yang berbeda pada budidaya ikan bandeng adalah Pengamatan pertumbuhan bobot harian ikan bandeng menunjukkan hasil yang tidak beda nyata antara perlakuan yang satu dengan yang lain, pengamatan bobot mutlak ikan bandeng menunjukkan berbeda nyata pada perlakuan D dengan nilai sebesar 2,01 gram, pengamatan panjang mutlak ikan bandeng menunjukkan hasil yang berbeda nyata antara perlakuan $\mathrm{C}$ dan $\mathrm{D}$ dengan perlakuan A dan B dengan nilai terbaik pada perlakuan $\mathrm{C}$ sebesar $4,50 \mathrm{~cm}$. Sedangkan rasio konversi pakan ikan bandeng menunjukkan hasil yang tidak berbeda nyata dengan nilai terendah pada perlakuan A dengan pemberian frekuensi pakan 1 kali.

Persentase kelangsungan hidup ikan bandeng pada semua perlakuan sebesar $100 \%$. Dengan padat penebaran ikan bandeng setiap perlakuan berjumlah 50 ekor.

Pengamatan kualitas air menunjukkan suhu air media budidaya berkisar 29,3 30,7 pada pagi hari, sedangkan sore hari berkisaran 29,0 - 31,2. $\mathrm{pH}$ media budidaya pada pagi hari berkisar $8,05-8,25$, sedangkan pada sore hari $8,06-8,29$. DO tertinggi didapatkan pada minggu ke2 sore yaitu $6,7 \mathrm{ppm}$ dan terendah pada minggu pertama pagi yaitu 6,1 ppm. Salinitas media budidaya berkisar 18-20 ppt.

\section{DAFTAR PUSTAKA}

Affan, J.M. 2012. Identifikasi Lokasi untuk Pengembangan Budidaya Keramba Jaring Apung (KJA) Berdasarkan Faktor Lingungan dan Kualitas Air di Perairan Pantai Timur Bangka Tengah. Depik, 1(1) : 78-85.

Dadiono, M.S., S. Andayani, K. Zailanie. 2017.The Effect of Different Dosage of Anredera cordifolia (Ten.) Steenis Leaves Extract towards the Survival Rate of African Catfish (Clarias sp.) Infected by Aeromonas salmonicida.International Journal of ChemTech Research. Vol. 10 (4) : 669-673.. 
Handajani dan Widodo. 2010. Kemampuan Mengikat Air oleh Tanah Pasir yang Diperlukan denganTepung Rumput Laut Gracilaria verrucosa. Laboratorium Biologi Struktur dan Fungsi Tumbuhan, Jurusan Biologi FMIPA UNDIP Hal.: 3238.

Karina, S. Rizwan dan Khairunnisak, 2011. Pengaruh Salinitas Dan Daya Apung Terhadap Daya Tetas Telur Ikan Bandeng. Jurnal Unsyiah. 1 (1) : 22-26.

Kordi, K.M.G.H., 2013. Budidaya Belut Di Pekarangan, Lahan Sempit, Lahan Kritis dan Minim Air. Sulawesi Selatan.

Mayunar, R. Purba, P.T. Imanto. 1995. Pemilihan lokasi budidaya ikan laut. Prosiding temu usaha pemasyarakatan teknologi keramba jaring apung bagi budidaya laut, Puslitbang Perikanan. Badan Litbang Pertanian: 179 - 189.

Rahim, A. R., Herawati, E. Y., Nursyam, H., Hariati, A. M. 2015. Cells Characteristics, Growth, and Quality of Gracilaria verrucosa Seaweed Production with Different Doses of Vermicompost Fertilizer. International Journal of Science Technology and Engineering, Volume 2, Issue 1.

Rahim, A. R., Herawati, E. Y., Nursyam, H., Hariati, A. M. 2016. Combination of Vermicompost Fertilizer, Carbon, Nitrogen and Phosphorus on Cell Characteristics, Growth and Quality of Agar Seaweed Gracilaria verrucosa. Nature Environment \& Pollution Technology, 15(4).

Rahim, A. R. 2018. Application of Seaweed Gracilaria verrucosa Tissue Culture using Different Doses of Vermicompost Fertilizer. Nature Environment and Pollution Technology, 17(2), 661-665.

Rahim, A. R. 2018. Utilization of Organic Wastes for Vermicomposting Using Lumbricus rubellus in Increasing Quality and Quantity of Seaweed Gracilaria verrucosa. Asian Journal of Microbiology, Biotechnology and Environmental Sciences. Volume 20, No. 2: 2018: S17 - S23.

Reksono, B. H. Hamdani, dan Yuniarti, 2012. Pengaruh Padatan Penebaran Gracilaria Sp Terhadap Pertumbuhan Dan Kelangsungan Hidup Ikan Bandeng Pada Budidaya Sistem Polikultur. Jurnal Perikanan Dan Kelautan. Vol 3 (3) : 41-49.

Serdiati, N., Yoel, Madinawati, 2011. Pemberian Pakan Yang Berbeda Terhadap Pertumbuhan dan Kelangsungan Hidup Benih Ikan Lele Dumbo (Clarias gariepinus). Jurnal Media Litbang Sulteng IV (2) : 83 - 87, Desember 2011. ISSN $1979-5971$.

Subandiyono dan S. Hastuti. 2011. Buku Ajar Nutrisi Ikan. Badan Penerbit Universitas Diponegoro, Semarang, $182 \mathrm{hlm}$.

William, R. dan N.S. Govind. Identification of carbohydrate degading bacteria in subtropical regions. Rev. Biol. Trop. 51, Supl. 4. 2003.

Yahya, Happy Nursyam, Yenny Risjani, dan Soemarno. 2014. Karakteristik Bakteri di Perairan Mangrove Pesisir Kraton Pasuruan. ILMU KELAUTAN Vol. 19. No.1.

Zverlova, V. V., W. Holl, dan H. Schwarz. Enzymes for digestion of cellulose and other polysaccharides in the gut of longhorn beetle larvae, Rhagium inquisitor L. (Col., Cerambycidae). International Biodeterioration \& Biodegadation. 51. 2003. 